\title{
Adaptation Pattern and Genetic Potential of Indian Pearl Millet Named Landraces Conserved at the ICRISAT Genebank
}

\author{
HD Upadhyaya ${ }^{1,2,3^{*}}$, KN Reddy ${ }^{1}$, Senthil Ramachandran ${ }^{1}$, Vinod Kumar ${ }^{1}$ and M Irshad Ahmed ${ }^{1}$ \\ ${ }^{1}$ Genebank, International Crops Research Institute for the Semi-Arid Tropics (ICRISAT), Patancheru, \\ Telangana-502324, India \\ ${ }^{2}$ Department of Agronomy, Kansas State University, Manhattan, KS 66506, USA \\ ${ }^{3}$ UWA Institute of Agriculture, University of Western Australia, Crawley WA 6009, Australia
}

(Received: 13 October 2015; Revised: 24 May 2016; Accepted: 25 May 2016)

\begin{abstract}
A total of 692 accessions belonging to 32 named landraces, adapted to a latitude range of $8.8^{\circ} \mathrm{N}$ to $30.90^{\circ} \mathrm{N}$ and originating in nine provinces of India were used to study their adaptation pattern and genetic potential. A clear pattern regarding association of latitude, climate at collection sites, adaptation of landraces and the agronomic performance was observed. Hierarchical cluster analysis using eight agronomic traits resulted in four clusters of accessions. Cluster 1 accessions flowered early and cluster 3 flowered late. Cluster 1 and cluster 4 accessions produced more tillers. Important sources identified were IP 13465 for early flowering and short height; IP 15273 for high tillering, high seed iron and zinc content and downy mildew resistance; IP 3531 for high seed protein content, downy mildew and rust resistance; IP 15285, IP 15288, IP 15290, IP 15301, and IP 15351 for high tillering.
\end{abstract}

Key Words: Adaptation pattern, Diversity, Genebank conservation, ICRISAT landraces, Pearl millet

In India, pearl millet [Pennisetum glaucum (L.) R. Br.] is the fifth most important cereal after rice, wheat, maize and sorghum and it is grown mainly for food, feed and fodder. Endowed with richness of landraces, India is the largest producer of pearl millet, both in terms of area (about 8.78 million hectares) and production (10.28 million tons) (Ministry of Agriculture, 2014). Major pearl millet growing states in India include Rajasthan, Maharashtra, Gujarat, Uttar Pradesh and Haryana.

Landrace is a dynamic population of a cultivated plant that has a historical origin, distinct identity and lacks formal crop improvement, as well as often being genetically diverse, locally adapted and associated with traditional farming system (Tania et al., 2005). Generally, traditional farmers or ethnic groups recognize and distinguish and name the landraces according to their maturity (early, medium and late) and grain characteristics (panicle shape and length, presence of bristles, grain size and color) or some other unique trait found in the material. Although yield is not high, the stability of named landraces in the face of adverse climatic conditions is typically higher than improved cultivars. Such named landraces developed through natural selection coupled with human selection over decades, offer a valuable genepool for future crop improvement programmes. There are many specific examples of the contribution of pearl millet named landraces or folk varieties towards the development of modern varieties. Best example is ICTP 8203, a variety developed at ICRISAT using Iniadi landrace originating in Togo. It was promising for early maturity, high seed yield, large seed size and downy mildew resistance and, has been released in India and Africa (Rai et al., 2008). Likewise, an $\mathrm{S}_{2}$ progeny of ICTP 8203 was identified as maintainer of $A_{1}$ cytoplasmicnuclear male sterility system in pearl millet (Rai et al., 2008). Further inbreeding and selection led to the development of maintainer line $863 \mathrm{~B}$ and its male-sterile counterpart $863 \mathrm{~A}$, which is a seed parent for three commercial hybrids in India (Rai et al., 2008). These examples indicate that the landrace Iniadi has unique combination of several useful traits, including high levels of resistance to multiple pathotypes of downy mildew, tolerance to terminal drought, high quality stover yield,

*Author for Correspondence: Email-H.Upadhyaya@cgiar.org 
higher levels of grain iron and zinc (Rai et al., 2008). Safeguarding and exploitation of these valuable resources along with related information is essential to enhance their utilization for sustainable pearl millet improvement. The genebank at ICRISAT conserves the world's largest collection of 22,888 pearl millet germplasm accessions from 51 countries including 6,610 accessions from India. Present study aimed at assessing the adaptation pattern and genetic potential of 32 most common pearl millet named landraces originated in India and assembled at ICRISAT genebank, to exploit their potential for pearl millet improvement, globally.

\section{Materials and Methods}

Passport and characterization data of the pearl millet named landraces originated in India and conserved at the ICRISAT genebank, were used in the present study. Named landraces, having georeferenced data and at least five or more accessions, were considered for the present study. A final set of 692 accessions belonging to 32 named landraces (hereafter called landraces) were used in the present study.

Landrace accessions were grown in batches of 500 to 1000 every year at ICRISAT, Patancheru, India in alfisols during the rainy and postrainy seasons from 1974 through 2013, as and when the new germplasm was added to the collection. During rainy season, accessions were sown in June and harvested in October/November. However, during postrainy season, accessions were sown in November and harvested in March of subsequent year. Two different seasonal conditions are typical to the semi-arid regions. The day length decreases from $13.20 \mathrm{~h}$ (in June) to $11.70 \mathrm{~h}$ (in October) with a mean of $12.6 \mathrm{~h}$ during rainy season and increases from 11.10 $\mathrm{h}$ (in December) to $12.00 \mathrm{~h}$ (in March) during postrainy season. The monthly mean minimum temperature varies from $22.4^{\circ} \mathrm{C}$ (in June) to $20.4^{\circ} \mathrm{C}$ (in October) and the monthly mean maximum temperature varied from $32.8^{\circ} \mathrm{C}$ (in June) to $28.2^{\circ} \mathrm{C}$ (in August) during rainy season. During postrainy season, monthly mean minimum temperature increased from $11.4^{\circ} \mathrm{C}$ (in December) to $19.4^{\circ} \mathrm{C}$ (in March) and the mean maximum temperature increased from $27.8^{\circ} \mathrm{C}$ (in December) to $33.1^{\circ} \mathrm{C}$ (in March). The mean annual rainfall at Patancheru was $877 \mathrm{~mm}$. Plot size consisted two rows of $4 \mathrm{~m}$ length, spaced at $75 \mathrm{~cm}$ between rows and $10 \mathrm{~cm}$ between plants within a row to accommodate 80 plants per plot. Accessions were randomized in all the evaluations with a control at every 20 test entries. Fertilizers were applied at the rate of $100 \mathrm{~kg} \mathrm{~N}$ and $40 \mathrm{~kg} \mathrm{P}_{2} \mathrm{O}_{5} \mathrm{ha}^{-1}$. Need based irrigations were given during rainy season, while the crop was irrigated at regular intervals during postrainy season. The crop was protected from weeds, pests and diseases.

Data were recorded on eight quantitative (days to $50 \%$ flowering, plant height, panicle length and thickness during rainy and postrainy seasons, total and productive tillers per plant, panicle exsertion and 1000 seed weight) and eight qualitative (panicle shape, panicle density, bristle length, green fodder yield potential, seed yield potential, seed shape and color, and endosperm texture) traits (IBPGR and ICRISAT, 1993). Days to $50 \%$ flowering, plant height, panicle length and thickness were recorded both during rainy and postrainy seasons. All other traits, except seed traits were recorded during rainy season. Seed traits were recorded during postrainy season. Emergence of stigma in $50 \%$ plants in a plot was recorded as days to $50 \%$ flowering. Mean height of five representative plants from base to the tip of plant was recorded in centimeters as plant height. Mean number of total and productive tillers was recorded in three plants. Distance between the ligule of the flag leaf and the base of panicle was recorded in centimeters as panicle exsertion. Panicle density was scored on 1-9 scale. Score 1-3 was considered as loose panicle, score 4-6 as intermediate and score 7-9 as compact panicle. Length of bristles was scored on 1-9 scale. Score 1-3 as short (bristles below the level of the apex of the seed), score 4-6 as medium (bristle length between 0 and $2 \mathrm{~cm}$ above the seeds) and score 7-9 as long (bristles longer than $2 \mathrm{~cm}$ above the seed). Endosperm texture was scored on 1-9 scale; score 1-3 as mostly corneous, 4-6 as partly corneous and 7-9 as mostly starchy. Green fodder yield potential was scored on 1-9 scale ( 1 being the poorest yielder and 9 as the excellent yielder) considering plant height, tillering, leafiness, etc. Seed yield potential was scored on 1-9 scale (1 being the poorest and 9 as the excellent yielder) considering number of productive tillers per plant, panicle size and seed size.

The high resolution $(1 \mathrm{~km})$ climatic data such as monthly mean (over past 30 years) day length, minimum and maximum temperature and mean annual rainfall 
for each collection site, was retrieved from http:// www.worldclim.org/current using the spatial analyst extension in ArcGIS ${ }^{\circledR}$ software (Hijmans et al., 2005). Averaged over crop season (June to November during rainy and November to March during postrainy season) at collection sites of landraces, the minimum, maximum and mean temperature, day length and mean annual rainfall for each landrace was estimated.

In the present study, photoperiod and temperature responses were defined by the difference in flowering during rainy and postrainy season (Upadhyaya et al. 2012). When the measurements (days to 50\% flowering) are high during the relatively cool shortday postrainy season, the accession was considered as temperature sensitive and requires higher temperature for flowering. When the measurements are high during the warm long-day rainy season, then the accession was considered as photoperiod sensitive and requires short days for flowering. When there was no difference in measurements (rainy-postrainy $=0$ days), then the accessions were considered as insensitive to both temperature and photoperiod. Database for disease reaction of pearl millet germplasm at ICRISAT genebank indicated that only a limited number of landrace accessions from India were evaluated for downy mildew, rust and nutritional traits such as seed protein, iron and zinc content, at ICRISAT, Patancheru, India (IBPGR and ICRISAT, 1993). Using the available data on nutritional traits and disease severity percentage, promising accessions within each landrace were identified for utilization in pearl millet improvement programmes.

Agronomic data of individual accessions were standardized by subtracting the mean value of the trait from each observation and subsequently dividing by its standard deviation. This resulted in standardized values for each trait with an average value of 0 and standardized deviation of 1 or less. The standardized values were used to perform principal component analysis (PCA) on Genstat 14 release (VSN International, 2010). Cluster analysis (Ward, 1963) was performed using scores of first five principal components (PCs) to group different landraces. Each cluster of landraces were plotted individually on political map of India. Mean, range and variances were calculated for eight quantitative characters in each cluster. The cluster means of different traits were compared using the
Newman-Keuls procedure (Newman, 1939; Keuls, 1952). Homogeneity of phenotypic variances was tested by Levene's test (Levene, 1960). Shannon and Weaver (1949) diversity index $\left(\mathrm{H}^{\prime}\right)$ was used to measure and compare the phenotypic diversity for all eight traits in each cluster. Phenotypic correlations were estimated among all quantitative characters and their significance was tested (Snedecor and Cochran, 1980). Frequencies were estimated for each class of qualitative traits.

\section{Results}

\section{The Collection}

The analysis of passport information of world collection of pearl millet germplasm at ICRISAT genebank, India, indicated India as the major source of germplasm with 6,610 accessions. The collection from India includes 6,064 landraces, 403 breeding materials, one advanced cultivar and 142 accessions of wild relatives. A total of 692 accessions belonging to 32 landraces under study had originated in nine provinces of India (Table 1).

\section{Cluster Analysis}

Principal Component Analysis (PCA) carried out using standardized data of eight quantitative traits captured $92.3 \%$ of total variation from the first five principal components (PCs). A hierarchical cluster analysis conducted on the scores of the first five PCs resulted in four clusters of landraces (Fig. 1 and Table 1). Cluster 1 consisted of 217 accessions of six landraces (Bchwaddawana, Chadi local, Desert type, Gullisita, Mahudo and Pitta ganti). Cluster 2 consisted of 150 accessions of four landraces (Barmer local, Jakhrana, Karauli and Sulkania), all from Rajasthan. Cluster 3 consisted of 121 accessions of seven landraces, all from Tamil Nadu. Cluster 4 consisted of 204 accessions of 15 landraces originating in Tamil Nadu (8), Andhra Pradesh (2), Gujarat (2), Maharashtra (4) and Uttar Pradesh (1).

\section{Adaptation of Landraces}

The collection under study was adapted to a latitude range of $8.8^{\circ} \mathrm{N}$ in Tamil Nadu to $30.90^{\circ} \mathrm{N}$ in Punjab (Fig. 1). Landraces of cluster 1 were adapted to a latitude range of $14.53^{\circ} \mathrm{N}$ to $30.90^{\circ} \mathrm{N}$ with mean latitude of $24.64^{\circ} \mathrm{N}$; those of cluster 2 from $24.00^{\circ} \mathrm{N}$ to $29.55^{\circ}$ $\mathrm{N}$ with mean latitude of $27.34^{\circ} \mathrm{N}$; those of cluster 3 from $8.79^{\circ} \mathrm{N}$ to $11.90^{\circ} \mathrm{N}$ with a mean of $9.97^{\circ} \mathrm{N}$ and 


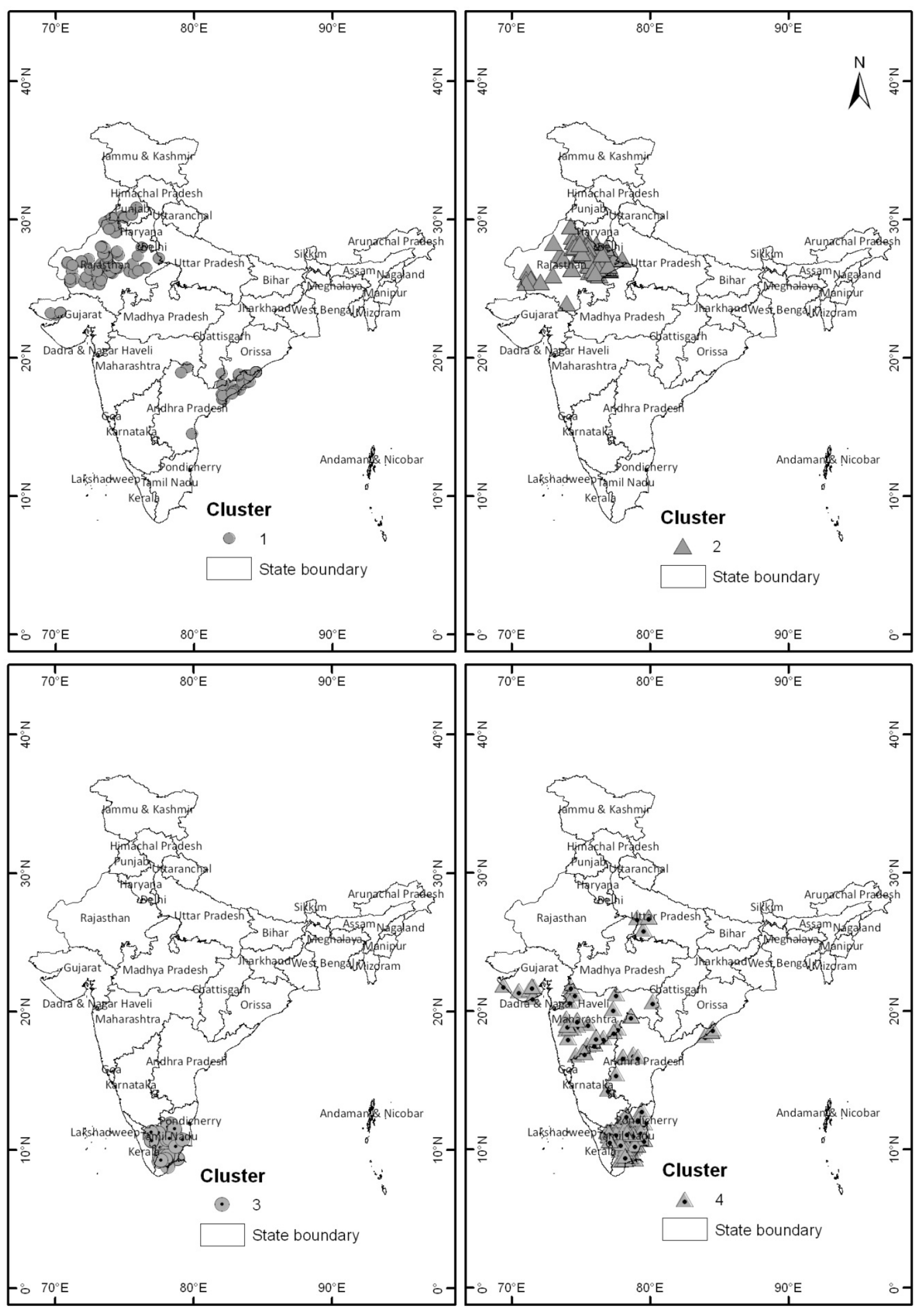

Fig. 1. Geographical adaptation of pearl millet named landraces from India, conserved at ICRISAT, India 
Table 1. Pearl millet named landraces from different provinces of India, conserved at ICRISAT, India

\begin{tabular}{|c|c|c|c|c|c|c|c|c|c|c|c|}
\hline Landrace & $\begin{array}{l}\mathrm{Cl} \\
\text { no. }\end{array}$ & $\begin{array}{l}\text { Andhra } \\
\text { Pradesh }\end{array}$ & Gujarat & Haryana & Maharashtra & Orissa & Punjab & Rajasthan & $\begin{array}{l}\text { Tamil } \\
\text { Nadu }\end{array}$ & $\begin{array}{l}\text { Uttar } \\
\text { Pradesh }\end{array}$ & Total \\
\hline Bchwaddawana & 1 & & & & & & 10 & & & & 10 \\
\hline Chadi local & 1 & & & 2 & & & 1 & 82 & & & 85 \\
\hline Desert type & 1 & & & & & & & 22 & & & 22 \\
\hline Gullisita & 1 & & & & & & 7 & 21 & & & 28 \\
\hline Mahudo & 1 & & 6 & & & & & & & & 6 \\
\hline Pitta ganti & 1 & 64 & & & & 2 & & & & & 66 \\
\hline Barmer local & 2 & & & & & & & 41 & & & 41 \\
\hline Jakhrana & 2 & & & 6 & & & & 5 & & & 11 \\
\hline Karauli & 2 & & & & & & & 89 & & 2 & 91 \\
\hline Sulkhania & 2 & & & & & & & 7 & & & 7 \\
\hline Eravai & 3 & & & & & & & & 8 & & 8 \\
\hline Kala cumbu & 3 & & & & & & & & 6 & & 6 \\
\hline Manavari & 3 & & & & & & & & 17 & & 17 \\
\hline Mathuravellai & 3 & & & & & & & & 39 & & 39 \\
\hline Peria cumbu & 3 & & & & & & & & 24 & & 24 \\
\hline Podi cumbu & 3 & & & & & & & & 22 & & 22 \\
\hline Umi & 3 & & & & & & & & 5 & & 5 \\
\hline Adchi & 4 & & & & 7 & & & & & & 7 \\
\hline Amreli & 4 & & 5 & & & & & & & & 5 \\
\hline Arisi & 4 & & & & & & & & 16 & & 16 \\
\hline Babapuri & 4 & & 8 & & 1 & & & & & & 9 \\
\hline Gaorani & 4 & & & & 27 & & & & & & 27 \\
\hline Kattu cumbu & 4 & & & & & & & & 44 & & 44 \\
\hline Kullan & 4 & & & & & & & & 20 & & 20 \\
\hline Mainpuri & 4 & & & & & & & & & 5 & 5 \\
\hline Nattu cumbu & 4 & & & & & & & & 17 & & 17 \\
\hline Oomi cumbu & 4 & & & & & & & & 8 & & 8 \\
\hline Pedda sajja & 4 & 11 & & & & & & & & & 11 \\
\hline Pokku cumbu & 4 & & & & & & & & 9 & & 9 \\
\hline Pottu cumbu & 4 & & & & & & & & 7 & & 7 \\
\hline Sadguru bajra & 4 & 5 & & & 4 & & & & & & 9 \\
\hline Vellai & 4 & & & & & & & & 10 & & 10 \\
\hline No. of accessions & & 80 & 19 & 8 & 39 & 2 & 18 & 267 & 252 & 7 & 692 \\
\hline
\end{tabular}

those of cluster 4 from $9.28^{\circ} \mathrm{N}$ to $26.83^{\circ} \mathrm{N}$ with a mean latitude of $13.93^{\circ} \mathrm{N}$. Mean latitudes of different clusters indicated that the landraces of cluster 1 and cluster 2 are from higher latitudes when compared to those of cluster 3 and cluster 4 . Out of 32 named landraces, a maximum of 15 landraces were adapted in Tamil Nadu followed by seven in Rajasthan, four in Maharashtra, three each in Andhra Pradesh, Gujarat and Punjab, two each in Haryana and Uttar Pradesh and one in Orissa (Table 1). Representation of individual landraces with more than 20 accessions in the collection suggested wide adaptation and extensive collection of Pitta ganti in Andhra Pradesh; Gaorani in Maharashtra; Barmer local, Chadi local, Desert type, Gullisita and Karauli in Rajasthan; Kattu cumbu, Mathuravellai, Peria cumbu and Podi cumbu in Tamil Nadu. 


\section{Diversity in the Collection}

\section{Qualitative traits}

Panicle shape: Out of nine panicle shapes in the world collection, six (cylindrical, conical, spindle, candle, lanceolate and oblanceolate) were found in the collection under study (IBPGR and ICRISAT, 1993). Cluster 1 and cluster 2 were the predominant sources for cylindrical shape, whereas cluster 3 and cluster 4 for candle shape with a frequency of more than $50 \%$ (data not given).

Panicle density: A maximum of $36 \%$ accessions scored 5 and only three accessions scored 7. IP 3144 and IP 3366 of Karauli scored 8 and were promising for compact panicle pearl millet.

Bristle length: 94\% accessions produced short bristles (bristles below the level of the apex of the seed) with a score of 1-3. IP 3278 of Gullisita and IP 3527 of Mathuravellai scoring 7 were the promising sources for bird-tolerant pearl millet.

Seed shape: Five seed shapes (obovate, oblanceolate, elliptical, hexagonal and globular) were found in the collection. Oblanceolate shape was predominant in cluster 2, 3 and 4 and elliptical shape was predominant in cluster 1 .

Seed color: Three (grey, deep grey and grey brown) of the 10 colour classes were found. Accessions producing grey seeds were predominant in cluster 2, cluster 3 and cluster 4 , whereas those producing grey-brown seeds were predominant in cluster 1 .

Endosperm texture: $26 \%$ of total accessions had corneous endosperm, a rich source of protein.

Green fodder yield potential: Sixty-six per cent accessions had the score of more than 5 for fodder yield, indicating the intense selection by farmers for high fodder yielding pearl millet. Among the clusters, $71 \%$ accessions of cluster $1,13 \%$ accessions of cluster 2, $49 \%$ each of cluster 3 and cluster 4 had a score of 7. Nineteen accessions belonging to 11 landraces had score of 8. IP 3188 and 3246 of Chadi local; IP 3173, IP 3190, IP 3245 of Desert type; IP 3517 of Eravai; IP 3586 of Kala cumbu; IP 3582 of Mathuravellai; IP 1305 and IP 3610 of Peria cumbu; IP 9101 and IP 17877 of Adchi; IP 1174 of Amreli; IP 9074 and IP 9076 of Gaorani; IP 3479, IP 3596 and IP 16238 of
Kattu cumbu and IP 16283 of Sadguru bajra had a score of 8 and these were promising for high green fodder yielding pearl millet.

Seed yield potential: Only nine (1\%) accessions scored 8 for seed yield. IP 3231, IP 3233, IP 3234 and IP 3239 of Chadi local; IP 3244 of Desert type; IP 9076 and IP 9119 of Gaorani; IP 3479 of Kattu cumbu and IP 3477 of Peria cumbu were identified as promising for high seed yield.

\section{Quantitative traits}

Range: Range of variation among the clusters for different agronomic traits indicated cluster 1 for early flowering $(<50$ days), short plant height and panicle length during postrainy season; cluster 2 for panicle length during rainy season; cluster 3 for early flowering ( $<50$ days) during rainy season and cluster 4 for short plant height during postrainy season, total and productive tillers, high panicle exsertion during rainy season, high panicle thickness during both seasons and high 1000 seed weight during postrainy season, showed wide variation (Table 2).

Range of variation for individual landraces indicated that the landraces from lower latitudes $\left(9^{\circ}-13^{\circ} \mathrm{N}\right)$ varied widely for days to flowering during rainy and postrainy season and plant height during rainy season when compared to those from higher latitudes (Table 3). Pitta ganti, Babapuri and Adchi for flowering during rainy season; Bchwaddawana and Pitta ganti for short height $(<135 \mathrm{~cm})$ and Mathuravellai and Eravai $(>390$ $\mathrm{cm})$ for tall height during rainy season; Oomi cumbu, Pokku cumbu, Vellai, Arisi, Mathuravellai, Nattu cumbu and Podi cumbu for short height $(<100 \mathrm{~cm})$ and Kattu cumbu $(335 \mathrm{~cm})$ and Karauli $(270 \mathrm{~cm})$ for tall height during postrainy season; Kattu cumbu and Chadi local, Pitta ganti for total tillers per plant; Kattu cumbu, Manavari and Pokku cumbu for productive tillers; Jakhrana, Karauli, Gullisita and Sulkania for long panicles $(40 \mathrm{~cm})$ during rainy and postrainy seasons; Gaorani, Jakhrana and Karauli for relatively larger seeds (>10 g/ 1000 seeds) were the important sources (Table 3).

Means: Mean values tested by Newman-Keuls test indicated significant differences among the clusters for one or more traits under study (Table 2). Accessions of cluster 1 flowered early during both the seasons, grew 
Table 2. Range, mean* and variance** for various traits of Indian pearl millet landraces in different clusters, evaluated at ICRISAT, India

\begin{tabular}{|c|c|c|c|c|c|c|c|}
\hline Trait & & Cluster 1 & Cluster 2 & Cluster 3 & Cluster 4 & F value & $\mathrm{P}$ \\
\hline \multirow[t]{3}{*}{ Days to $50 \%$ flowering- $R$} & Range & $38-74$ & $46-69$ & $47-135$ & $43-119$ & & \\
\hline & Mean & $57.0 \mathrm{~d}$ & $61.0 \mathrm{c}$ & $93.1 \mathrm{a}$ & $68.0 \mathrm{~b}$ & & \\
\hline & Variance & 46.9 & 19.9 & 257.8 & 318.0 & 44.2 & $<0.0001 * *$ \\
\hline \multirow[t]{3}{*}{ Days to $50 \%$ flowering-PR } & Range & $50-101$ & $52-78$ & $55-94$ & $45-95$ & & \\
\hline & Mean & $67.4 \mathrm{c}$ & $70.7 \mathrm{~b}$ & $73.8 \mathrm{a}$ & $67.9 \mathrm{c}$ & & \\
\hline & Variance & 37.6 & 26.1 & 48.6 & 64.5 & 5.7 & $<0.0001 * *$ \\
\hline \multirow[t]{3}{*}{ Plant height $(\mathrm{cm})-\mathrm{R}$} & Range & $120-269$ & $155-299$ & $200-416$ & $146-384$ & & \\
\hline & Mean & $194.4 d$ & $231.7 \mathrm{c}$ & $328.9 \mathrm{a}$ & $245.2 b$ & & \\
\hline & Variance & 871.0 & 867.0 & 1820.0 & 3656.0 & 45.8 & $<0.0001 * *$ \\
\hline \multirow[t]{3}{*}{ Plant height $(\mathrm{cm})-\mathrm{PR}$} & Range & $100-255$ & $110-270$ & $88-210$ & $60-335$ & & \\
\hline & Mean & $184.5 b$ & $205.9 \mathrm{a}$ & $143.4 \mathrm{c}$ & $149.3 \mathrm{c}$ & & \\
\hline & Variance & 740.3 & 688.6 & 446.9 & 965.1 & 2.4 & $0.071 \mathrm{NS}$ \\
\hline \multirow[t]{3}{*}{ Total tillers (no.) } & Range & $1-18.5$ & $1-7.7$ & $1-16.5$ & $1-18.5$ & & \\
\hline & Mean & $4.4 \mathrm{a}$ & $2.9 \mathrm{~b}$ & $3.3 b$ & $4.6 \mathrm{a}$ & & \\
\hline & Variance & 5.5 & 1.2 & 4.8 & 13.0 & 9.0 & $<0.0001 * *$ \\
\hline \multirow[t]{3}{*}{ Productive tillers (no.) } & Range & $1-8$ & $1-6.8$ & $1-10.7$ & $1-12.5$ & & \\
\hline & Mean & $3.1 \mathrm{a}$ & $2.6 \mathrm{~b}$ & $2.0 \mathrm{c}$ & $3.3 \mathrm{a}$ & & \\
\hline & Variance & 1.9 & 0.8 & 2.0 & 5.8 & 12.0 & $<0.0001 * *$ \\
\hline \multirow[t]{3}{*}{ Panicle exsertion $(\mathrm{cm})$} & Range & $-8-15$ & $-3-15$ & $-10-14$ & $-9-17$ & & \\
\hline & Mean & $7.1 \mathrm{~b}$ & $6.3 b$ & $4.7 \mathrm{c}$ & $8.0 \mathrm{a}$ & & \\
\hline & Variance & 13.0 & 11.0 & 14.4 & 18.0 & 1.7 & $0.1583 \mathrm{NS}$ \\
\hline \multirow[t]{3}{*}{ Panicle length (cm)-R } & Range & $14-43$ & $19-50$ & $15-40$ & $12-35$ & & \\
\hline & Mean & $21.4 \mathrm{c}$ & $30.3 \mathrm{a}$ & $25.4 \mathrm{~b}$ & $21.5 \mathrm{c}$ & & \\
\hline & Variance & 12.4 & 35.0 & 17.6 & 22.0 & 11.6 & $<0.0001 * *$ \\
\hline \multirow[t]{3}{*}{ Panicle length (cm)-PR } & Range & $11-50$ & $13-45$ & $11-27$ & $8-31$ & & \\
\hline & Mean & $16.8 \mathrm{~b}$ & $22.9 \mathrm{a}$ & $16.9 \mathrm{~b}$ & $17.5 b$ & & \\
\hline & Variance & 15.5 & 23.7 & 12.0 & 17.3 & 1.4 & $0.256 \mathrm{NS}$ \\
\hline \multirow[t]{3}{*}{ Panicle thickness (mm)-R } & Range & $13-30$ & $15-28$ & $14-27$ & $12-35$ & & \\
\hline & Mean & $19.6 b$ & $19.4 \mathrm{~b}$ & $18.9 b$ & $20.8 \mathrm{a}$ & & \\
\hline & Variance & 9.2 & 5.0 & 6.8 & 17.5 & 20.8 & $<0.0001 * *$ \\
\hline \multirow[t]{3}{*}{ Panicle thickness (mm)-PR } & Range & $12-30$ & $12-28$ & $11-25$ & $10-31$ & & \\
\hline & Mean & $18.4 \mathrm{~b}$ & $19.7 \mathrm{a}$ & $15.2 \mathrm{c}$ & $19.1 \mathrm{ba}$ & & \\
\hline & Variance & 10.9 & 8.2 & 8.3 & 24.2 & 28.6 & $<0.0001 * *$ \\
\hline \multirow[t]{3}{*}{ 1000-Seed weight (g) } & Range & $3.2-9.7$ & $4.1-10.55$ & $2.5-8.5$ & $2-10.7$ & & \\
\hline & Mean & $6.8 \mathrm{~b}$ & $7.7 \mathrm{a}$ & $5.5 \mathrm{c}$ & $6.3 b$ & & \\
\hline & Variance & 1.6 & 1.1 & 1.2 & 3.8 & 35.4 & $<0.0001 * *$ \\
\hline
\end{tabular}

* Means were tested by using student Newman-Keuls test; means followed by different letter are significantly different at $\mathrm{p}=0.05$,

** variances were tested using Leven's test 


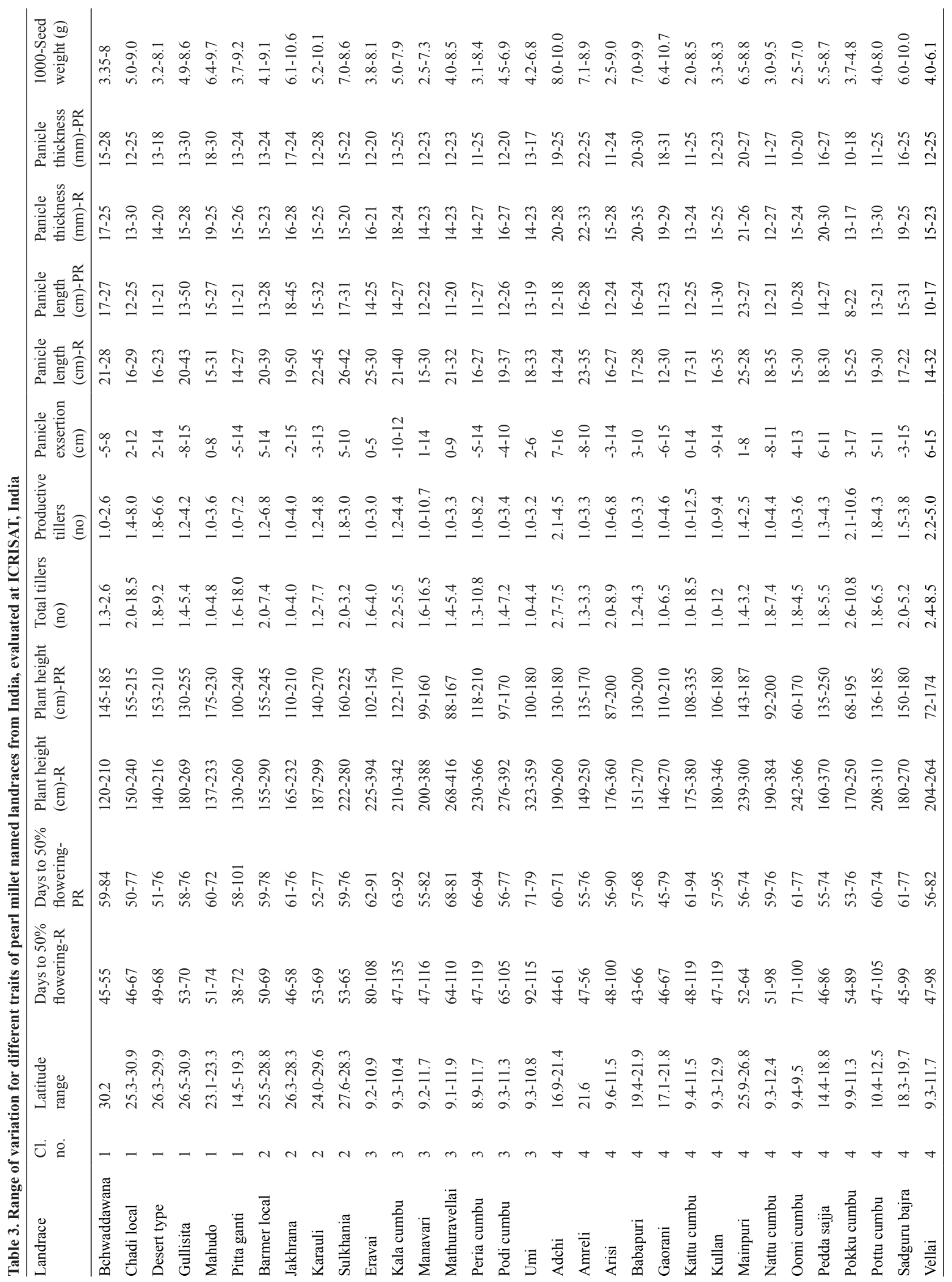

Indian J. Plant Genet. Resour. 29(2): 97-113 (2016) 


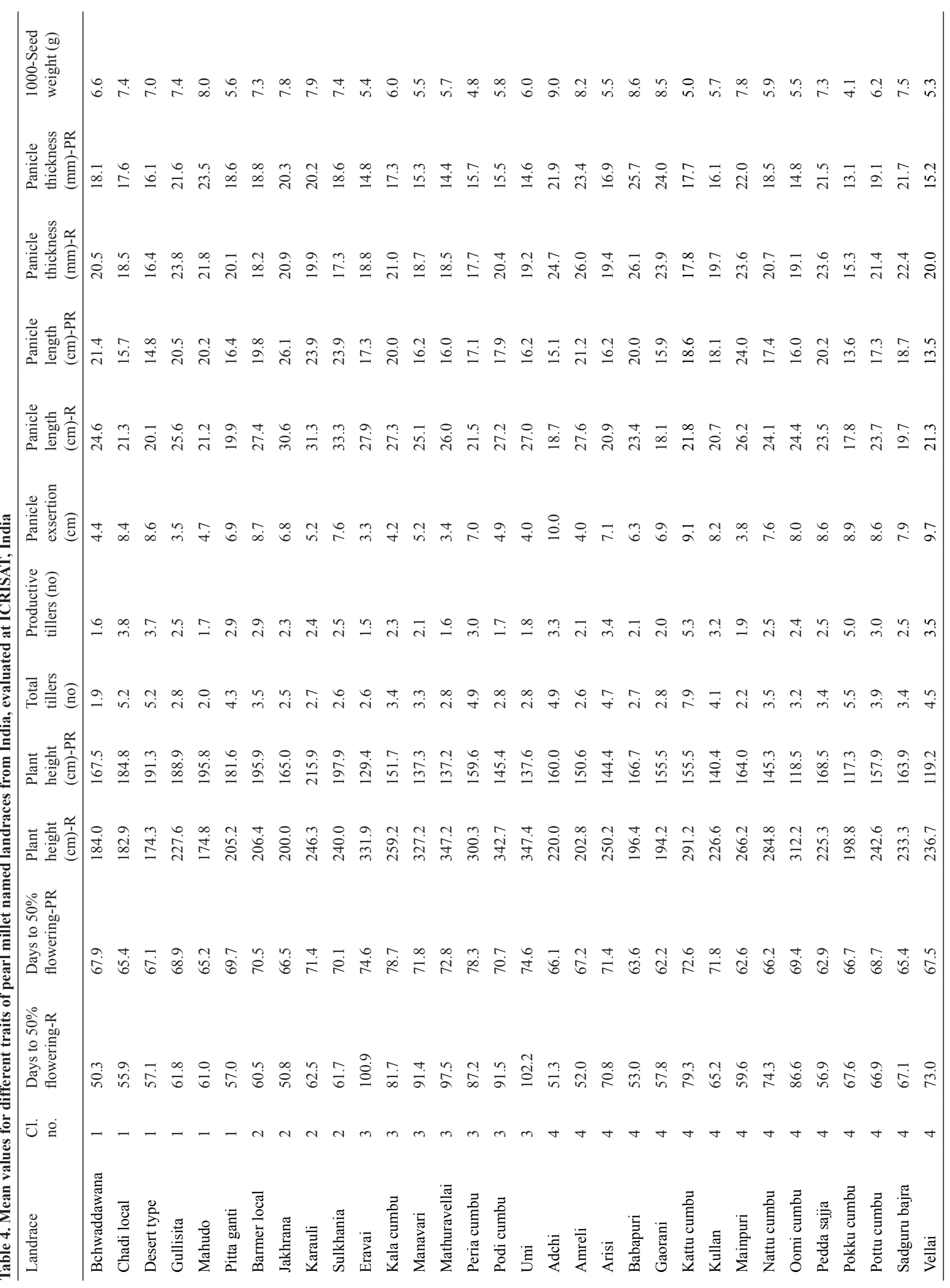

Indian J. Plant Genet. Resour. 29(2): 97-113 (2016) 
less and produced many total as well as productive tillers during rainy season; those of cluster 2 produced long panicles during both the seasons and produced stout panicles and larger seeds during postrainy season; those of cluster 3 grew less during postrainy season and those of cluster 4 produced many total as well as productive tillers and highly exserted stout panicles during rainy season. Cluster 2 during postrainy season and cluster 3 during rainy season were good sources for tall accessions.

Mean values for individual landraces indicated that all landraces from lower latitudes $\left(9^{\circ} \mathrm{N}-13^{\circ} \mathrm{N}\right)$ flowered late ( $>65$ days) during rainy and postrainy season and grew tall $(>250 \mathrm{~cm})$ during rainy season and relatively short $(<160 \mathrm{~cm})$ during postrainy season and produced small and thin panicles (Table 4).

Variances: The homogeneity of variances for different clusters and eight quantitative traits was tested by Levene's test (Levene, 1960). The variances were heterogeneous $(\mathrm{p}=0.001)$ for days to $50 \%$ flowering during both the seasons, plant height during rainy season, total and productive tillers, panicle length during rainy season, panicle thickness during both the seasons and 1000 seed weight, which was recorded during postrainy season (Table 2). Variance was more in cluster 4 for plant height and panicle exsertion during rainy season.

Phenotypic diversity: Mean Shannon-Weaver diversity $\left(\mathrm{H}^{\prime}\right)$ over all traits was maximum $\left(\mathrm{H}^{`}=0.598 \pm 0.006\right)$ in cluster 2 (Table 5). Mean diversity over clusters indicated maximum diversity $\left(H^{`}=0.616 \pm 0.004\right)$ for 1000 seed weight. Among the clusters, cluster 1 for days to $50 \%$ flowering during postrainy season; cluster 2 for 1000 seed weight; cluster 3 for panicle exsertion and cluster 4 for panicle thickness during rainy season were highly diverse with maximum diversity index $\left(\mathrm{H}^{\prime}\right)$.

\section{Correlations}

Twenty-four correlations were highly significant and positive, 29 were highly significant and negative, one significant and positive, and three significant and negative (Table 6). Days to 50\% flowering during rainy season had highly significant positive correlation with days to $50 \%$ flowering during postrainy season, plant height and panicle length during rainy season. Days to $50 \%$ flowering during postrainy season also had highly significant positive association with plant height during rainy and postrainy seasons and panicle length during rainy season and highly significant negative correlation

Table 5. Shannon-Weaver (H') diversity index for different traits of Indian pearl millet landraces in different clusters, evaluated at ICRISAT, India

\begin{tabular}{|c|c|c|c|c|c|c|}
\hline Trait & Cluster 1 & Cluster 2 & Cluster 3 & Cluster 4 & Mean & $\mathrm{Se}+$ \\
\hline Days to $50 \%$ flowering- $\mathrm{R}$ & 0.602 & 0.590 & 0.537 & 0.568 & 0.574 & 0.0142 \\
\hline Days to $50 \%$ flowering-PR & 0.614 & 0.550 & 0.512 & 0.618 & 0.573 & 0.0259 \\
\hline Plant height $(\mathrm{cm})-\mathrm{R}$ & 0.613 & 0.623 & 0.564 & 0.567 & 0.592 & 0.0152 \\
\hline Plant height $(\mathrm{cm})-\mathrm{PR}$ & 0.591 & 0.608 & 0.609 & 0.606 & 0.604 & 0.0041 \\
\hline Total tillers (no.) & 0.513 & 0.589 & 0.436 & 0.392 & 0.483 & 0.0434 \\
\hline Productive tillers (no.) & 0.571 & 0.594 & 0.320 & 0.377 & 0.466 & 0.0687 \\
\hline Panicle exsertion $(\mathrm{cm})$ & 0.605 & 0.604 & 0.636 & 0.542 & 0.597 & 0.0199 \\
\hline Panicle length $(\mathrm{cm})-\mathrm{R}$ & 0.573 & 0.600 & 0.622 & 0.582 & 0.594 & 0.0108 \\
\hline Panicle length $(\mathrm{cm})-\mathrm{PR}$ & 0.536 & 0.585 & 0.593 & 0.630 & 0.586 & 0.0195 \\
\hline Panicle thickness (mm)-R & 0.604 & 0.623 & 0.588 & 0.636 & 0.613 & 0.0107 \\
\hline Panicle thickness (mm)-PR & 0.625 & 0.585 & 0.551 & 0.596 & 0.589 & 0.0153 \\
\hline 1000-Seed weight (g) & 0.609 & 0.624 & 0.610 & 0.621 & 0.616 & 0.0038 \\
\hline Mean & 0.588 & 0.598 & 0.548 & 0.561 & 0.574 & \\
\hline $\mathrm{Se} \pm$ & 0.0098 & 0.0061 & 0.0262 & 0.0252 & 0.0140 & \\
\hline
\end{tabular}

$\mathrm{R}=$ Rainy and $\mathrm{PR}=$ Postrainy season 
with panicle exsertion, panicle thickness during rainy and postrainy season, and 1000 seed weight. Strong positive correlation between days to $50 \%$ flowering and plant height during rainy season $(\mathrm{r}=0.811)$ explains more than $50 \%$ variation and suggests that selection for early flowering will result in selection of accessions with less height. Similarly, total tiller per plant showed strong positive correlation with productive tillers per plant $(\mathrm{r}=0.884)$ indicating the selection for more total tillers per plant results in selection for more productive tillers per plant. Selection for long panicles during rainy season results in selection for pearl millet producing long panicles during postrainy season indicating the less effect of season on panicle length. Differences in correlation coefficients of trait combinations during rainy and postrainy seasons may be attributed to the effect of photoperiod and temperature sensitivity of the accessions.

\section{Climate}

A clear pattern regarding association of latitude of collection sites, climatic factors and adaptation of named landraces was observed in the collection under study (Fig. 2). As expected, the highest monthly mean day length and maximum temperature at collection sites of landraces originated at higher latitudes (cluster 1 and cluster 2 and Mainpuri, Amreli, Babapuri, Sadguru bajra, Gaorani and Adchi of cluster 4) was relatively higher than all landraces of cluster 3 and remaining landraces of cluster 4 and it increased with the increase in latitude. Highest monthly mean minimum temperature also followed the pattern of latitude. On the other hand, lowest monthly mean minimum temperature deviated from the pattern of latitude and reduced with the increase in latitude of collection sites. All landraces, except Pitta ganti, in cluster 1 with mean latitude of more than $20^{\circ} \mathrm{N}$ had received mean annual rainfall ranging between 294-422 $\mathrm{mm}$. On the other hand, collection sites of Pitta ganti with latitude range of $14.5^{\circ}-19.3^{\circ} \mathrm{N}$ had received mean annual rainfall of $1149 \mathrm{~mm}$. Collection sites of landraces in cluster 2 received mean annual rainfall ranging between $390-562 \mathrm{~mm}$, those of cluster 3 received $778-883 \mathrm{~mm}$ and those of cluster 4 received 573-954 mm.

\section{Identification of Promising Sources}

Promising sources were identified within each cluster for different agronomic and nutritional traits, photoperiod and temperature insensitivity, salinity and disease resistance (Table 7).

\section{Agronomic traits}

Of the 692 accessions under study, 203 accessions $(29 \%)$ belonging to 29 landraces $(90 \%$ landraces under study) originating in nine provinces, were identified as the promising sources for one or more traits. Among the provinces, accessions from Tamil Nadu were promising for fodder yield and those from Rajasthan, Andhra Pradesh and Maharashtra for early flowering ( $<50$ days) during rainy season. Among the clusters,

\begin{tabular}{|c|c|c|c|c|c|c|c|c|c|c|c|}
\hline Trait & 1 & 2 & 3 & 4 & 5 & 6 & 7 & 8 & 9 & 10 & 11 \\
\hline 2 & 0.478 & & & & & & & & & & \\
\hline 3 & 0.811 & 0.426 & & & & & & & & & \\
\hline 4 & -0.308 & 0.089 & -0.215 & & & & & & & & \\
\hline 5 & 0.054 & 0.029 & -0.006 & -0.076 & & & & & & & \\
\hline 6 & -0.070 & -0.015 & -0.112 & 0.015 & 0.884 & & & & & & \\
\hline 7 & -0.194 & -0.186 & -0.228 & 0.025 & 0.288 & 0.297 & & & & & \\
\hline 8 & 0.088 & 0.144 & 0.293 & 0.263 & -0.259 & -0.214 & -0.36 & & & & \\
\hline 9 & -0.190 & 0.043 & 0.054 & 0.400 & -0.184 & -0.122 & -0.221 & 0.615 & & & \\
\hline 10 & -0.276 & -0.251 & -0.107 & 0.065 & -0.327 & -0.312 & -0.187 & 0.106 & 0.175 & & \\
\hline 11 & -0.464 & -0.309 & -0.293 & 0.364 & -0.180 & -0.108 & -0.07 & 0.124 & 0.418 & 0.527 & \\
\hline 12 & -0.477 & -0.284 & -0.377 & 0.389 & -0.319 & -0.247 & -0.018 & 0.205 & 0.255 & 0.396 & 0.461 \\
\hline
\end{tabular}

Correlations $\geq 0.088$ are significant at $\mathrm{p}=0.01 \%$ and $\geq 0.062$ are significant at $\mathrm{p}=0.05 \%$ at $690 \mathrm{df}$

$1=$ Days to $50 \%$ flowering-R, $2=$ Days to $50 \%$ flowering-PR, $3=$ Plant height $(\mathrm{cm})-\mathrm{R}, 4=$ Plant height $(\mathrm{cm})-\mathrm{PR}, 5=$ Total tillers (no), $6=$ Productive tillers (no), $7=$ Panicle exsertion $(\mathrm{cm}), 8=$ Panicle length $(\mathrm{cm})-\mathrm{R}, 9=$ Panicle length $(\mathrm{cm})-\mathrm{PR}, 10=$ Panicle thickness $(\mathrm{mm})-\mathrm{R}, 11=$ Panicle thickness (mm)-PR, 12 = 1000-Seed weight $(\mathrm{g})$ 


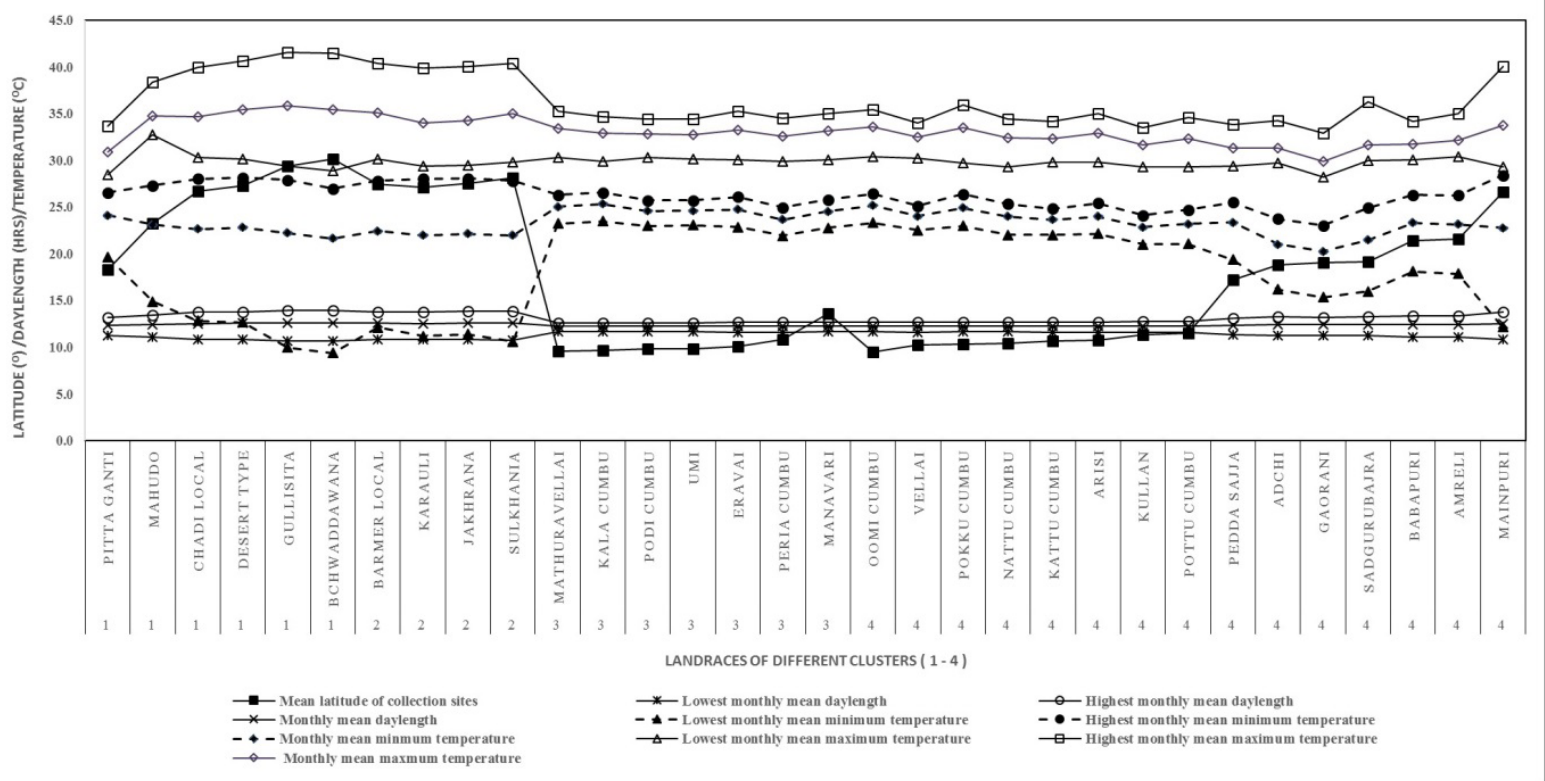

Fig. 2. Climatic factors at the collection sites of pearl millet named landraces from India, conserved at ICRISAT, India

Table 7. Promising landraces identified for different agronomic and nutritional traits and biotic and abiotic stresses, evaluated at ICRISAT, India

\begin{tabular}{lll}
\hline Trait & $\begin{array}{l}\text { Cluster } \\
\text { no. }\end{array}$ & Promising source : Landrace (IP no.) \\
\hline
\end{tabular}

\section{Agronomic traits}

Days to $50 \%$ flowering - $\mathrm{R}(<50 \quad 1$ days)
Bchwaddawana (IP 1417, 1418, 1425, 1427), Chadi local (3155, 3172, 3175, 3220, 3226, 3231, $3235,3239,3252,3253,3435,13586)$, Desert type $(3230,3251)$, Pitta ganti $(1249,1251,1252$, 11782-11784, 11786, 11787, 11789-11792, 11794, 11867, 11868, 11873, 11877, 11878, 13460, 13465)

2 Jakhrana (IP 1478-1480, 3123 and 11885),

3 Kala cumbu (1315), Manavari (1304), Peria cumbu (1307)

4 Adchi (9101, 9105, 17867), Arisi (15329 and 15412), Babapuri (1179, 3840, 12556), Gaorani (9107, 9113, 9115, 9121, 9122, 9146, 13554), Kattu cumbu (15335, 15373), Kullan (1306), Pedda sajja (11810, 11811), Sadguru bajra $(1266,1267,7813)$ and Vellai (13600)

\begin{tabular}{|c|c|c|}
\hline $\begin{array}{l}\text { Days to } 50 \% \text { flowering - PR }(<50 \\
\text { days) }\end{array}$ & 4 & Gaorani $(4144,4148$ and 4149$)$ \\
\hline \multirow[t]{2}{*}{ Plant height-R $(<150 \mathrm{~cm})$} & 1 & $\begin{array}{l}\text { Bchwaddawana }(1416,1425) \text {, Desert type (3245 and 3264), Mahudo }(3865,3857) \text {, Pitta ganti } \\
(3018,13465)\end{array}$ \\
\hline & 4 & Amreli (3807), Gaorani $(4148,4150)$ \\
\hline \multirow[t]{2}{*}{ Plant height-PR $(<100 \mathrm{~cm})$} & 3 & Manavari (3576), Mathuravellai (3582), Podi cumbu (3577) \\
\hline & 4 & $\begin{array}{l}\text { Arisi (3475), Nattu cumbu (3573), Oomi cumbu (3569, } 3570 \text { and 3572), Pokku cumbu (3583, } \\
3589,3590 \text { and 3591), Vellai (3487 and 3574) }\end{array}$ \\
\hline \multirow[t]{2}{*}{ Plant height-R $(>375 \mathrm{~cm})$} & 3 & $\begin{array}{l}\text { Eravai (3495), Manvari (3516 and 3554), Mathuravellai }(3498,3499,3508,3515,3544) \text {, Podi } \\
\text { cumbu }(3525,3529,3532)\end{array}$ \\
\hline & 4 & Kattu cumbu $(3568,3597)$ and Nattu cumbu $(3559)$ \\
\hline
\end{tabular}

Contd. 


\begin{tabular}{|c|c|c|}
\hline Traits & $\begin{array}{l}\text { Cluster } \\
\text { No. }\end{array}$ & Promising source : Landrace (IP no.) \\
\hline \multirow[t]{3}{*}{ Plant height-PR $(250-350 \mathrm{~cm})$} & 1 & Gullisita (3274) \\
\hline & 2 & Karauli $(3366,3367,3370,3382)$ \\
\hline & 4 & Kattu cumbu (16238) \\
\hline \multirow[t]{3}{*}{ Total tillers $(15.5-18.5)$} & 1 & Chadi local (13584), Pitta ganti (3036) \\
\hline & 3 & Manavari (15341) \\
\hline & 4 & Kattu cumbu $(3628,15285,15288,15290,15301,15302,15304,15342$ and 15351) \\
\hline \multirow[t]{3}{*}{ Panicle length-R (42-50 cm) } & 1 & Gullisita (13575) \\
\hline & 2 & Jakhrana (13581), Karauli $(3338,3349,3393,3395,13582)$ and Sulkania (3316) \\
\hline & 4 & Adchi (17877) and Gaorani (13552) \\
\hline \multirow[t]{3}{*}{ Green fodder yield potential (score 8) } & 1 & Chadi local $(3188,3246)$, Desert type (3173 and 3190) \\
\hline & 3 & Eravai (3517), Kala cumbu (3586), Peria cumbu $(1305,3610)$ \\
\hline & 4 & $\begin{array}{l}\text { Amreli (1174), Gaorani (9074 and 9076), Kattu cumbu (3479 and 3596) and Sadguru bajra } \\
\text { (16283) }\end{array}$ \\
\hline \multirow[t]{3}{*}{ Seed yield potential (score 8) } & 1 & Chadi local $(3233,3234)$, Desert type $(3244,3245)$ \\
\hline & 3 & Peria cumbu (3477) \\
\hline & 4 & Gaorani (9119) \\
\hline \multicolumn{3}{|l|}{ Nutritional traits } \\
\hline Sweet stalk & 3 & Podi cumbu (3471), Podi cumbu (3481), Mathuravellai (3509) and Umi (3593) \\
\hline \multirow[t]{2}{*}{ High seed protein $(>15.0 \%)$} & 3 & Peria cumbu $(3611,3615,3626)$, Podi cumbu (3481) and Mathuravellai (3620) \\
\hline & 4 & Oomi cumbu (15400), Kullan (3531), Arisi (3631) \\
\hline \multirow[t]{4}{*}{ High seed iron and zinc ( $>50 \mathrm{ppm})$} & 1 & Chadi local (3432), Gullisita (11044), Mahudo (3859), Pitta ganti (11799) \\
\hline & 2 & Karauli $(3329,3331)$ \\
\hline & 3 & Podi cumbu (3525), Peria cumbu (3626) \\
\hline & 4 & Kullan (3642), Pedda sajja (11811), Kattu cumbu (15273) \\
\hline \multicolumn{3}{|l|}{ Biotic stresses } \\
\hline \multirow[t]{4}{*}{ Downy mildew resistance } & 1 & Chadi local (3220), Gullisita (3274), Pitta ganti (3060) \\
\hline & 2 & Karauli $(3146,3359,3382)$ \\
\hline & 3 & Manavari (3492), Mathuravellai $(3509,3526,3582)$, Podi cumbu $(3543,13603)$, Umi (3486) \\
\hline & 4 & Arisi (3480), Kattu cumbu $(3479,15273)$, Kullan $(3484,3531)$ and Mainpuri $(13620)$ \\
\hline Rust resistance & 4 & Kullan (3531), Pedda sajja (8521) \\
\hline \multicolumn{3}{|l|}{ Abiotic stresses } \\
\hline Heat tolerance & 1 & Chadi local (3175) \\
\hline Salinity tolerance & 3 & Peria cumbu (3616) \\
\hline \multirow{3}{*}{$\begin{array}{l}\text { Photoperiod and temperature } \\
\text { insensitivity }\end{array}$} & 1 & Chadi local $(3228,3419)$ \\
\hline & 2 & Barmer local (3304) and Karauli (3331) \\
\hline & 4 & Arisi (3617), Mainpuri (6901) and Kattu cumbu (15433) \\
\hline
\end{tabular}

$44.3 \%$ accessions of cluster $4,30 \%$ of cluster $1,23 \%$ of cluster 2 and $22 \%$ of cluster 3 were promising for one or more traits. A total of 64 accessions belonging to six landraces in cluster 1 for ten traits, 25 accessions of three landraces in cluster 2 for five traits, 25 accessions of six landraces in cluster 3 for seven traits and 89 accessions of 14 landraces in cluster 4 for 14 traits were superior over the other accessions. Among the landraces, Chadi local and Manavari for five traits, Gaorani and Kattu cumbu for seven traits, were identified as important sources. In the entire collection, range of variation indicated 71 accessions belonging to 18 landraces as promising for early flowering ( $<50$ days) during rainy season (Table 7). Only three accessions of Gaorani (IP 4144 IP 4148 and IP 4149) were identified for early flowering ( $<50$ days) during postrainy season. In the 
collection, 11 accessions of six landraces for short plant height $(<150 \mathrm{~cm})$ during rainy season, 14 accessions of eight landraces for short height during postrainy season; 14 accessions of six landraces for tallness $(>375 \mathrm{~cm})$ during rainy season and six accessions of three landraces for tallness $(250-350 \mathrm{~cm})$ during postrainy season, were important sources (Table 7).

\section{Drought tolerance}

Generally, pearl millet grown in low rainfall dry regions is considered a good source ofdrought-tolerance. Annual mean rainfall at the collection sites of cluster 1 landraces $(<425 \mathrm{~mm})$ was low when compared with that of cluster 2, cluster 3 and cluster 4 . Low annual mean rainfall averaged over all collection sites of Desert type accessions $(294 \mathrm{~mm})$ in cluster 1 indicated that they could be good sources for drought-tolerant pearl millet.

\section{Photoperiod and temperature insensitivity}

A maximum of $92.6 \%$ accessions in cluster $1,94.7 \%$ in cluster $2,55.4 \%$ in cluster 4 and $13.2 \%$ in cluster 3 had shown temperature sensitivity (Table 7 ). On the other hand, $86.8 \%$ accessions in cluster $3,42.6 \%$ in cluster $4,6.5 \%$ in cluster 1 and $4 \%$ in cluster 2 had shown photoperiod sensitivity. Two accessions (IP 3228 and 3419) of Chadi local; IP 3304 of Barmer local; IP 3617 of Arisi; IP 6901 of Mainpuri; IP 3331 of Karauli and IP 15433 of Kattu cumbu were promising sources for photoperiod and temperature insensitive pearl millet.

\section{Nutritional traits}

Pearl millet germplasm database for seed quality traits indicated the evaluation of limited number of accessions under study for these traits. One accession each of Chadi local, Gullisita, Mahudo, Pitta ganti, Karauli, Podi cumbu, Peria cumbu, Kullan, Pedda sajja and Kattu cumbu were promising sources with more than $50 \mathrm{ppm}$ seed iron and zinc (Table 7). Peria cumbu, Podi cumbu, Mathuravellai, Oomi cumbu, Kullan and Arisi were important sources for high seed protein content (>15\%) (Table 7). IP 3471, IP 3481, IP 3509 and IP 3593 were sweet stalks with high stalk soluble sugar content $(17-19 \%)$.

\section{Diseases resistance}

Pearl millet germplasm database for disease reaction of accessions indicated that at least one accession each of
Chadi local, Gullisita, Pitta ganti, Karauli, Manavari, Mathuravellai, Podi cumbu, Umi, Arisi, Kattu cumbu, Kullan, Mainpuri for downy mildew and Kullan and Pedda sajja for rust were the sources of resistance for downy mildew and rust with $<5 \%$ disease severity (Table 7).

\section{Multiple traits}

IP 13465 of Pitta ganti was found promising for early flowering (38 days to 50\% flowering) and short height $(<150 \mathrm{~cm})$ during rainy season (Table 7). Eight accessions of Kattu cumbu (IP Nos. 15273, 15285, $15288,15290,15301,15302,15342$ and 15351) were found as promising for more productive as well as total tillers. IP 15273 was also found promising for high seed iron and zinc content ( $>50 \mathrm{ppm}$ ) and downy mildew resistance. IP 3531 of Kullan for high seed protein content, downy mildew and rust resistance; IP 3479 of Kattu cumbu for high fodder as well as seed yield potential with downy mildew resistance, were the other promising sources.

\section{Discussion}

Named landraces, evolved from conscious selection over decades by farmers for desirable traits, were considered as time tested cultivars. In India, many farmers still use landraces and often retain them even when they experiment with and adopt modern varieties. High adaptation to varying agroclimatic conditions, high fodder yield, yield stability, resistance to abiotic and biotic stresses, perception of good quality food, nutritional and processing qualities, traditional intercropping patterns, religious ceremonies and filling unique market niches are the main reasons for liking of landraces by farmers. Because of open pollination in farmer's fields, landraces are heterogeneous populations and farmers grow such landraces either as a sole crop or mix with improved cultivars with a strong belief that they will harvest something from landraces even if they lose the crop of improved cultivars under adverse conditions (Jarvis et al., 2008). Smithson and Lenne (1996) reported the reduction in pest and disease attack, and higher yield stability due to poly-cultivar cropping. There is a need to foster diversity in food production and consumption, and thus improved food and nutritional security (Khourya et al., 2014). Therefore, adoption of wide range of cultivars or landraces is emphasized 
worldwide, to boost the genetic diversity and thus reduce the genetic vulnerability of the world food system in the face of challenges including climate change and rising food demand.

The landraces under study were adapted to a wide range of latitudes $\left(8.8^{\circ} \mathrm{N}\right.$ to $\left.30.9^{\circ} \mathrm{N}\right)$ and these were cultivated in more than one province. Variation in latitude of collections will have the impact on diversity among landraces. The close association of latitude and climatic conditions at collection sites and agronomic performance of landraces under study indicates no effect of geographic province (Upadhyaya et al., 2007; Upadhyaya et al., 2014). In the present study, landraces of cluster 1, except Pitta ganti, and those of cluster 2 were adapted to higher latitudes $\left(14.53^{\circ} \mathrm{N}\right.$ to $\left.30.90^{\circ} \mathrm{N}\right)$ characterized by longer days, higher mean maximum temperature and low mean annual rainfall $(<425 \mathrm{~mm})$. These flowered relatively earlier (mean 57-61days) than those from lower latitudes (mean latitude $<13^{\circ} \mathrm{N}$ ). These landraces may be useful in breeding early-medium maturing drought/temperature-tolerant varieties of pearl millet (Fig. 2) (Upadhyaya et al., 2014). All landraces of cluster 3 and Arisi, Kattu cumbu, Kullan, Nattu cumbu, Oomi cumbu, Pokku cumbu, Pottu cumbu, and Vellai of cluster 4 were from lower latitudes, characterized by day length close to $12 \mathrm{~h}$ and lower monthly mean minimum and maximum temperature. Probably due to sensitivity of the accessions to the climate, these landraces flowered late (mean 68-93days) and grew relatively tall during rainy season and short during postrainy season. At higher latitudes, lowest monthly mean minimum temperature was inversely proportion to the latitude of the collection site and was an important determinant of adaptation and diversity pattern (Upadhyaya et al., 2014). According to Upadhyaya et al. (2014), there was wide variation in pearl millet landraces from lower latitudes.

Accessions of Desert type, collected from very low rainfall $(<300 \mathrm{~mm})$ areas reflect the naming of landraces by farmers based on suitability of the material to deserts. Continuous selection over decades in dry regions might have resulted in Desert type landraces. Such landraces could be a good source for drought and heat tolerance and suitable for cultivation in drier regions of India. Upadhyaya et al. (2007) reported that the arid zone in India, characterized by low rainfall $(<500 \mathrm{~mm})$ and high temperatures $\left(>35^{\circ} \mathrm{C}\right)$, could be a better site for growing early maturing, short and high tillering pearl millet. However, number of rainy days and the amount of rainfall play an important role in deciding the length of growing period in any region (Gadgil et al., 1988). Yadav et al. (2003) reported local landraces as a good source of adaptive genetic variation for tolerance to drought and represent suitable breeding material for arid zone environments.

Accessions with high seed zinc content identified in the study could be useful in developing nutrient dense pearl millet varieties to reduce the problem of malnutrition in India. Sweet stalk accessions identified would provide good quality fodder (Appa Rao et al., 1982). Downy mildew and rust are the important diseases of pearl millet causing severe crop losses. Although pearl millet hybrids often give better grain yield than do the landraces, they are vulnerable to biotic and abiotic stresses. In such situations, the landrace germplasm identified as promising for downy mildew and rust are very useful in developing downy mildew- and rustresistant pearl millet varieties and hybrids.

Because of continuous threat to the on-farm landraces due to their replacement by modern cultivars, natural calamities, urbanization, etc., specific measures are needed to safeguard them for future sustainable agriculture and food security (Upadhyaya and Gowda, 2009). Such measures include filling gaps in germplasm collections, documentation of landraces for indigenous knowledge, increasing awareness about role of landraces in sustainable agriculture and food security, establishing community genebanks conserving seeds of landraces for easy access to the smallholder farmers. Representation of India in world collection of pearl millet germplasm is impressive with 6,610 accessions. However, Upadhyaya et al. (2010) reported 134 districts of 14 provinces in India as geographical gaps and 208 districts of 12 provinces as gaps in trait-specific diversity. The collection sites of promising sources, identified in the present study, may be considered while launching collection missions to have more promising sources in the world collection. Tamil Nadu province, which was a good source with 15 out of 32 named landraces under study, may be further explored to enrich the diversity in fodder type pearl millet collection at ICRISAT. Upadhyaya et al. (2007) also recommended launching 
germplasm collection programme in Tamil Nadu for high tillering pearl millet.

The promising sources identified in the present study are useful to broaden the genetic base of new cultivars and enhance the use of available germplasm resources. However, further evaluation of these sources for agronomic, nutritional and climate-related traits, and also for biotic stress resistance is needed for immediate release as varieties and also for long-term use in pearl millet improvement programmes. Seeds of all landrace accessions named in present study are available at ICRISAT genebank, India, for research and training purposes, under Standard Material Transfer Agreement (SMTA) of the International Treaty on Plant Genetic Resources for Food and Agriculture (ITPGRFA).

\section{Acknowledgements}

Authors sincerely acknowledge the contribution of all former and present staff of genebank at ICRISAT, Patancheru, India in collection, assembly and conservation of pearl millet genetic resources. The help of Sube Singh, Lead Scientific Officer in analysing the data is gratefully acknowledged. The help of D Bapa Rao and G Ram Reddy, research technicians, in recording observations and documentation is highly appreciated.

\section{References}

Appa Rao S, MH Mengesha and V Subramanyam (1982) Collection and preliminary evaluation of sweet-stalk pearl millet (Pennisetum). Economic Botany 36: 286-290.

Gadgil S, AKS Huda, NS Jodha, RP Singh and SM Virmani (1988) The effects of climatic variations on agriculture in dry tropical regions of India. In: Parry ML, TR Carter and NT Konjin (eds). The Impact of Climatic Variations on Agriculture. Vol. 2. Assessments in Semi-Arid Regions. Kluwer Academic Publishers. Dordrecht/Boston/London, International Institute for Applied Systems Analysis, United Nations Environment Program.

Hijmans RJ, SE Cameron, JL Parra, PG Jones and A Jarvis (2005) Very high resolution interpolated climate surfaces for global land areas. Int. J. Climatology 25: 1965-1978. doi: 10.1002/joc.1276. website http://www.worldclim.org/ current in June 2011.

IBPGR and ICRISAT (1993) Descriptors for pearl millet [Pennisetum glaucum (L.) R. Br.]. International Board for Plant Genetic Resources, Rome, Italy; International Crops Research Institute for the Semi-Arid Tropics, Patancheru, India. $\mathrm{p} 43$.
Jarvis DI, AHD Brown, PH Coung and L Collado-Panduro (2008) A global perspective of the richness and evenness of traditional crop-variety diversity maintained by farming communities. Proc. Nat. Acad. Sci (USA) 105: 5326-5331.

Keuls M (1952) The use of the "Studentized range" in connection with an analysis of variance. Euphytica 1: 112-122.

Khourya CK, AD Bjorkmanc, H Dempewolfd, J Ramirez-Villegas, Luigi Guarino, Andy Jarvis, LH Rieseberg and PC Struik (2014) Increasing homogeneity in global food supplies and the implications for food security. Proc. Nat. Acad. Sci. (USA) 111: 4001-4006. DOI: 10.1073/pnas.1313490111

Levene H (1960) Robust tests for equality of variances. In: Olkin I (ed.) Contributions to Probability and Statistics: Essays in honour of Harold Hotelling. Stanford University Press, Stanford, pp 278-292.

Ministry of Agriculture (2014) Status paper on coarse cereals. Directorate of millets development, Jaipur. Department of agriculture and cooperation, Government of India.

Newman D (1939) The distribution of range in samples from a normal population expressed in terms of an independent estimate of standard deviation. Biometrika 31: 20-30.

Rai KN, CT Hash, AK Singh and G Velu (2008) Adaptation and quality traits of a germplasm derived commercial seed parent of pearl millet. Plant Genet. Resour. Newslett. 154: 20-24.

Shannon CE and W Weaver (1949) The Mathematical Theory of Communication. University of Illinois Press, Urbana, USA.

Smithson JB and JM Lenne (1996) Varietal mixtures: A viable strategy for sustainable productivity in sustainable agriculture. Annals Appl. Biol. 128: 127-158.

Snedecor GW and WG Cochran (1980) Statistical methods, $7^{\text {th }}$ Edn. Iowa State University Press, Ames, USA.

Tania Carolina CV, Nigel Maxted, Maria Scholten and Brian Ford Lloyd (2005) Plant Genet. Resour. Characterization and Utilization 3: 373-384.

Upadhyaya HD and CLL Gowda (2009) Managing and enhancing the use of germplasm - strategies and methodologies. Technical Manual no.10. Patancheru 502 324, Andhra Pradesh, India: International Crops Research Institute for the Semi-Arid Tropics. $236 \mathrm{p}$.

Upadhyaya HD, KN Reddy, CLL Gowda, M Irshad Ahmed and Sube Singh (2007) Agroecological patterns of diversity in pearl millet [Pennisetum glaucum (L.) R. Br.] germplasm from India. J. Plant Genet. Resour. 20: 178-185.

Upadhyaya HD, KN Reddy, M Irshad Ahmed and CLL Gowda (2010) Identification of gaps in pearl millet germplasm from Asia conserved at the ICRISAT genebank. Plant Genet. Resour. 8: 267-276.

Upadhyaya HD, KN Reddy, M Irshad Ahmed, Naresh Dronavalli and CLL Gowda (2012) Latitudinal variation and distribution 
of photoperiod and temperature sensitivity for flowering in the world collection of pearl millet germplasm at ICRISAT genebank. Plant Genet. Resour. 10: 59-69.

Upadhyaya HD, KN Reddy, Sube Singh, CLL Gowda, M Irshad Ahmed and Senthil Ramachandran (2014) Latitudinal patterns of diversity in the world collection of pearl millet landraces at the ICRISAT genebank. Plant Genet. Resour. 12: $91-102$.
VSN International (2010). GenStat software for windows. Release 13.1. VSN International Ltd., Hemel Hempstead, UK.

Ward JH (1963) Hierarchical grouping to optimize an objective function. J. Am. Stat. Assoc. 58: 236.

Yadav OP, E Weltzien-Rattunde and FR Bidinger (2003) Genetic variation for drought response among landraces of pearl millet. (Pennisetum glaucum). Indian J. Genet. Plant Breed. 63: 37-40. 